INDEPENDENT JOURNAL OF MANAGEMENT \& PRODUCTION (IJM\&P)

\title{
RAISING BRAND AWARENEES THROUGH THE INTERNET MARKETING TOOLS
}

Margarita Išoraitè Vilniaus kolegija/University Applied Sciences, Lithuania

E-mail:misoraite@gmail.com

Submission: $20 / 10 / 2015$

Revision: 24/11/2015

ABSTRACT

Accept: 04/12/2015

The opinions of different authors on raising brand awareness. The article are analyzes the opinions of different authors on raising brand awareness. The concept of internet marketing and its implementation ilt also describes and analyzes the concept of internet marketing and its implementation. The analysis investigation of the most urgent and the most effective online marketing tools in developing brand awareness are provided in the article. The article analyses website, internet advertising, social networks and the search engine optimization.

Keywords: brand, brand awareness, internet, advertising, internet marketing 


\section{INTRODUCTION}

Broken brands in the world are ranked by a wide variety of criteria, such as: awareness, monetary value, consumer affection, love appreciation, loyalty, etc. If you measure the success of brands like speed, during which the mark reaches the incumbent necessary strength parameters of the previous decades, and the world really has successful brands.

This list will inevitably arise in particularcan be the following: Apple, Amazon, Google, and Facebook. Every year the importance of the internet is increasing. For every brand it is important to create brand awareness. Brand awareness was analyzed by the following Lithuanian authors: Černikovaitè (2011), Treigytè and Pikturnienè (2009). Furthermore, brand awareness was also analyzed by these foreign authors: Aaker (1996), Arora et al (2013), Aperia et al (2004), Chan et al (2015), Campbell et al (2011), Chi et al (2011) and others.

The aim of the article is to assess brand awareness through the internet marketing tools. Brand awareness is tThe research object - brand awareness. Research problems arise from research investigative questions "Are internet marketing tools raising brand awareness?"

\section{RESEARCH METHODOLOGY}

Scientific literature analysis reveals theoretical aspects of raising brand awareness, internet marketing concept, and internet marketing tools.

\section{THE CONCEPT OF BRAND AWARENESS RAISING}

Hoffman, Fodor, (2010) stated that traditionally brand awareness is measured through tracking studies and surveys. Online, however, marketers have a number of ways to track brand awareness. In the social media environment, the company gains increased exposure to its brand, often in highly relevant contexts every time a person uses an application created by or about the company.

According Keller (2009), the concept of brand equity and the important intangible value that brands bring to organizations has been the most popular and potentially important marketing topic, emerging in recent years. 
DOI: 10.14807/ijmp.v7i2.391

Homburg, Klarmannn, and Schmitt (2010) argue that brand awareness informs us about this product. Branding campaigns have a unique goal to increase the value of the product, service or other matter, advertising awareness and visibility.

Pikturniene (2009) admits that the brand awareness (memory, vision, decision-making environment) is a necessary condition for selection.

Černikovaite (2011) argues that brand awareness can be a prerequisite to buy the product. The high quality of the goods or services encourage users to buy and produce means an additional profit. Brand associations are typical consumer attitudes to brand, the company delivers their advertising. Such associations can enrich the brand by new features, perceived by the creation of added value, providing consumers with a positive impact on safety or exclusivity, increasing the value of the brand.

Urbanskienè et al (2006) asserts that brand awareness indicates whether this brand raises the consumer's mind and his thought of a certain category of goods and whether it happens quickly. This is one of the main dimensions of the value of the brand. Incidentally, it is important that brand evaluation of the individual user's position is useless, if the user does not know the whole analyzed brand.

Thus, new original target of the brand is well known, but it maintains a high level of awareness on the market. It also states that the user's aspect on the brand's image can be analyzed through associations, arising when the user analyzes the brand in mind. Association assessments may be: brand association prototypes (features, benefits, common position of brand terms); loyalty, strength, and uniqueness. Apart that, the brand must not be limited to the superposition that brand name's recognition is very important and this causes the association with trademark, when the user attempts to grasp it.

Probably the most important part of the company's strategic plan is to attract new customers and keep them loyal to the business. Loyal customers increase the company's turnover; the increase of company's awareness is a great tool to increase customer's loyalty. Raising awareness among the young people is particularly important for every company for successful expanding of their business in the future, because if the business is not done in time, no new clients grow older existing loyal 
INDEPENDENT JOURNAL OF MANAGEMENT \& PRODUCTION (IJM\&P)

http://www.ijmp.jor.br

v. 7, n. 2, April - June 2016

ISSN: 2236-269X

DOI: 10.14807/ijmp.v7i2.391

customers, that ultimately result in the general decline in customer volumes (ROESLER, 2015).

Every day a variety of messages come to us; various manufacturers want to tell us about their products or services. Their main goal is to acquire the advertised product or service, and also increase the company's visibility. Hsiao (2011) mentions several authors opinions: "this is the buyer's ability to recognize and distinguish the brand so that he immediately understands the goods category owned by the trademark. For example, if someone mentioned the well-known theater name, most people immediately recognize it, and think it is the cinema."

\section{Table 1: Concept brand awareness}

\begin{tabular}{|l|l|}
\hline Author & Concept \\
\hline $\begin{array}{l}\text { Somayeh Shojaee } \\
\text { and Azreen bin } \\
\text { Azman (2013) }\end{array}$ & $\begin{array}{l}\text { Brands awareness could be raised through marketing communication channels, } \\
\text { which notify, remind, and convince customers about their brands, products or } \\
\text { services. }\end{array}$ \\
\hline Kelly (2015) & Brand awareness is one of the most commonly cited goals of marketers today. \\
\hline $\begin{array}{l}\text { Arora and Sharma } \\
\text { (2013) }\end{array}$ & $\begin{array}{l}\text { There are three strategic roles that help to build the brand. Marketers must use } \\
\text { social media to serve their brand building objectives. It can help the brand to: } \\
\text { build a relationship to become more trusted; } \\
\text { differentiate through an emotional connection to become more } \\
\text { remarkable and unmistakable; and }\end{array}$ \\
nurture loyal fans to become more essential.
\end{tabular}


DOI: 10.14807/ijmp.v7i2.391

\begin{tabular}{|l|l|}
\hline & $\begin{array}{l}\text { well-convinced brand positioning. Marketing messages can be designed and } \\
\text { delivered through both traditional media such as television, radio, newspapers } \\
\text { and on-line media such as internet and social media. Marketers have found } \\
\text { that interactive and targeted marketing are the keys to success and that } \\
\text { traditional advertising is essentially a waste of money. }\end{array}$ \\
\hline $\begin{array}{l}\text { Zailskaite-Jakste, } \\
\text { Kuvykaite (2013) }\end{array}$ & $\begin{array}{l}\text { In social media brand becomes dependent on the wish and will of a consumer. } \\
\text { Consumers themselves decide how to interpret a brand, i.e. shared creativity } \\
\text { between a brand and consumers. Companies seeking to expand brand } \\
\text { awareness must learn to communicate in such a way when a mess age would } \\
\text { spread among consumers like a virus. Word-of-mouth communication or viral } \\
\text { marketing when used together with other marketing communications means } \\
\text { can increase brand equity. Therefore companies have to prepare for the } \\
\text { communication with consumers. }\end{array}$ \\
\hline $\begin{array}{l}\text { Karam, Saydam } \\
\text { (2015) }\end{array}$ & $\begin{array}{l}\text { The brand awareness has turned into an important variable that impacts } \\
\text { customer's perceptions of a brand. Achievement in brand management arises } \\
\text { from understanding and overseeing brand image and loyalty correctly to create } \\
\text { strong characteristics that will impact consumers when making on their } \\
\text { decisions. }\end{array}$ \\
\hline
\end{tabular}

Brand awareness can be divided into two main parts:

- Brand's recognition. People have heard or seen the brand, but their consciousness can be completely "locked", meaning that they are about this brand and will remember it only in the case if someone mentions it.

- Well-known trade marks. These are the brands that most people remember. Most often these are the trademarks of the services that people use most often (Hshio (2013).

Koniewski (2011) asserts that in total there are five levels of brand awareness:

- Company's or brand's rejection and negative associations. If somebody associates the company or brand with something negative, especially if they avoid the company's products or services provided. This can happen for the following reasons, such as: negative customer's complaints, product defects, and other causes that may impair public's opinion about the company or brand.

- Company's reputation. People were thinking about the company, allowing the decision, if they have not heard about your company, or know what it staprovides. In order to avoid this, it should make the brand to be much easier to remember, become associated with something uniquely different from the others.

- Company's recognition. After reaching this level, customer immediately recognizes the name of the company and knows what it is performing. This allows increasing the company's turnover, because people usually choose the 
DOI: 10.14807/ijmp.v7i2.391

company that they know and have heard about, rather than any other about which they have heard for the first time.

- Priority. Potential customers have two choices between two different companies and they can choose where to set up their business. This usually happens due to differentiation. Consumers know which the company is doing in the other way and best meets the needs of the users, the quality of services and communication.

- Loyalty. Users regularly choose your company, even if they occasionally suffer from poor service quality, or if the a new product with much higher quality and more attractive price entered the market. In order to win the loyalty of users, you need to give them a product that is clearly and strongly differentiated to customers. Visitors need to provide the highest service and its quality that they will not find anywhere else. And finally, the companies have constantly grow together with the customers and adapt to their constantly changing needs.

Brands are remembered with external assistance, if people remember these brands only after someone mentions them, or in case they place them somewhere in their notes; but if people search in their mind for some brands, they will not remember them (KONIEWSKI, 2012).

Keller (2009) states that there is a wide range of possible benefits (HOEFFLER; KELLER, 2003): improved perceptions of product performance; greater customer's loyalty; less vulnerability to competitive marketing actions and marketing crises; larger margins; more flexible customer's response to price decreases and inflexible customer's response to price increases; greater trade or intermediary cooperation and support; increased marketing communication effectiveness; additional licensing and brand extension opportunities.

\section{INTERNET MARKETING CONCEPT}

Tsimonis, Dimitriadis (2014) argues during the past decade that the rapid evolution of the internet has offered consumers many new opportunities. Besides the obvious use of searching for information and communicating without boundaries, nowadays it is possible to express feelings and thoughts through social media. First, 
a real internet marketing tool could be distinguished with the emergence of websites in 1990 .

The first simple websites provided people with basic information about the company, services, or products. However, internet content has improved and expanded, the new tools had emerged (pictures, sounds and video clips). The internet marketing execution was one of the most important areas of our lives as the internet occupies more and more of our personal time.

Chi (2011) defines social media marketing as a "connection between brands and consumers, offering a personal channel and currency for the user, centered networking and social interaction."

Campbell (2011) states that internet marketing "is much more to do with what people are doing with the technology, than the technology itself, for rather than merely retrieving information, users are now creating and consuming it, and hence adding value to the websites that permit them to do so".

Somayeh, Azreen bin Azman (2013) admits that improving the level of brand awareness is one of the marketers' challenges, as reflected in the complicated funnel. Brands need to make a strong association with customers in order to achieve the different levels of brand awareness, recognition, recall, top of the mind and become dominant,. The existing researches, brand exposures, customers engagement and electronic-word-of-mouth are the factors helping to evaluate the impacts of social media on brand awareness.

Vukasovič (2013) states that the internet provides the opportunity for the companies to reach a wider audience and create compelling value propositions that was not possible before (e.g., Amazon.com range is 4.5 million book titles), while providing new tools for promotion, interaction, and relationship building.

Different authors defined internet marketing in different manner, but essentially all definitions are similar. Internet marketing means marketing activities that are carried out in the Internet space, using the existing web-based tools. Internet marketing includes not only advertising on the websites, but also the factors, such as: e-mails, social networks, etc (Trengove,2011). 
Davidavičiene (2009) states that internet marketing is the internet and related digital technologies marketing objectives and modern marketing concept support. One of the biggest mistakes in business development and the execution of internet marketing strategy is the fact that they did not think forward at least five steps.

A lot of companies are constantly trying to develop and execute internet marketing as soon as possible, without any clear plan, but with the purpose or results to set targets for any guidance that after a certain period of time compared to the company's fulfilled certain actions.

Perfectly planned and executed Internet marketing strategy makes it very easy to distinguish between companies that are committed to work in long-term perspective, from other companies which carry out internet marketing simply because the market says that it must perform.

The latter company can be very easily separated, there is a lack of information on websites, the shortage of images will be complemented, or will be updated, These are just a few examples of companies that still not fully understand the internet marketing potential, how much it can help to expand their business, and reach a much larger audience of potential customers with relatively very low costs (SWEENEY, 2006).

According to the author, one of the most emerging business people questions is how all planned internet marketing strategy corresponds nowadays of constantly evolving and changing technology. The best solution to this question is to answer this question: "How do you plan to expand your business?".

If the business cannot answer this question, then he has even bigger problem, and it should be resolved. If the company has the answer to this question, then the forecast should be set where they be successful in six months, a year or even longer; and accordingly, to create a strategy that will cover both the company's product development and sales (SWEENEY, 2006).

\section{INTERNET MARKETING TOOLS}

\subsection{Website}

Website, dedicated to the brand, is potentially the most powerful brand building tool. Company's website is the most important element of internet marketing 
DOI: 10.14807/ijmp.v7i2.391

then any online activity. This is the company's second home online where customers and visitors can, at any time and from anywhere, to visit and see the latest news, offers, or products.

However, if the website is designed poorly or not appealing to the eye, slow and has unnecessary element,s or simply is unattended, it may bring more losses than benefits, because the website visitors will have a negative opinion about the company and its activities, and it is very likely that in the future they might not attend such page and even avoid the real shop.

Hill (2011) distinguished the following five key points to create a beautiful and user-friendly website:

Bar. Perhaps the most important part of the URL, poorly designed it can make a website completely unusable and eventually scare away visitors. Very important not to overload the field of design, but at the same time to create something beautiful, colourful and flickering. The simpler the design, the easier it will be to understand and manage website.

Brand integrity of the company. If the company has developed and is developing its own brand, it is essential to move it into a website design, as customers and visitors share website design together with the company's brand. This result also creates a single corporate brand integrity.

Text layout. Most people prefer reading a web page as well as a book from the top to the bottom, from the left to the right. During creation of a web page, the most important information should be made on the right top side, in order relevant and updated information will be seen immediately and very easily.

Content. The creation of a short and clear message allows visitors to read information, understand and remember it simpler and easier. Visitors simply get lost, if the site is swamped with information, they do not understand where and what to read, they will not remember the information they obtain, and finally get tired of reading and leave the website. So, writing a text, one must remove completely unnecessary information and create more white space between rows, and make the text easier to read on the screen. 
DOI: 10.14807/ijmp.v7i2.391

Trust. Creation of more beautiful, more attractive and appealing to more clients and visitors website that meets the needs of web design, allows the company to form a larger and stronger sense of mutual trust. It can also be extended and the return of goods guarantee to pay for the goods only after delivery of things to your home or reservation.

People will notice it immediately and positively assess it; the recovery will be felt in the enterprise. It is not enough creating a beautiful website; it is necessary to maintain a warm, pleasant and fast relationship between employees, the existing and potential customers (HILL, 2011).

Summing up, if the company has created really beautiful and with a very wellthought-out web page, where everything is in place and a common commodity description integrity, the website guests will obviously visit it. Internet visitors will get more convenient and eager to browse the website, which will definitely contribute to the improvement of the image of the company. Some companies are improving their public image when existing customers provide positive feedback.

\subsection{Advertising on the internet}

According to the Adjugler (2008), almost 15-20 years ago, when the internet has just started to spread and gain its popularity, the internet advertising space can be compared with advertising in the media. Customers bought advertising space in a desired site for a certain period of time and placed it without knowing, whether the advertisement would interest visitors.

Advertising rates were determined by simply taking into account the advertising space and the average amount of site visitors, even without knowing whether they will see the ad or not. Media is following perhaps the same principle, only the price is determined according to the market circulation.

Such advertising was and is very inefficient for attracting visitors and showing the prices, so the advancing technology improved advertising opportunities. Over time it appeared more modern and efficient advertising when changing few ads at the same ad space, so it was possible to find out which ads are more interesting to visitors or completely uninteresting. 
DOI: $10.14807 /$ ijmp.v7i2.391

Still later it appeared in "cost per thousand advertising principle", a standard set of advertising cost per thousand website visitors, where the advertisement was displayed. Over the time, more similar to modern times, payment models, "cost per click" (pre-determined price for a click on an ad) principle emerged, and the number of clicks can be shown.

For a while, advertising became much imaginative, with moving animations, etc. Modern software became so sophisticated that it is able to provide advertising exclusively in a particular region or population to provide advertising to different people, based on demographic data.

Although there are numbers of promotional tools, but a perfect tool for all advantages and disadvantages still does not exist. Finally, the use of promotional tools varies widely from the advertiser to the objectives and the audience, so this should also be taken into account (ADJUGLER, 2008).

According to Chan (2015), using internet and traditional advertising, both contribute to the company's brand promotion and awareness-raising. Author used the present literature, confirming that internet advertising is especially effective tool to improve the company's brand awareness.

According to him, the advanced modern internet technology allows internet users to apply only the most relevant and updated information on exactly what they need without any unwanted content. Using the latest and the most efficient analytical data processing programs, Internet users can get ideas on certain issues as well as understand and investigate their deeds.

And most importantly, all of this information comes from social networks, online forums or discussions. This allows businesses to provide the most important and most relevant content to consumers that meets their expectations in order to increase their awareness of the society companies can "run noise" in the Internet space. This can be done by creating a viral video or advertise widely throughout cyberspace in order to promote positive public feedback "word of mouth" (CHAN, 2015). 
DOI: 10.14807/ijmp.v7i2.391

\subsection{Social networks}

Social media marketing involves the use of internet social media tools, such as: Facebook, Twitter, and Linkedln in order to reach consumers innovatively. Social networking helps promoting the company and its activities. Active social networks try to attract more new customers or visitors. People are always much more interested in following corporate social networking, than just visiting their websites.

In social networks people can directly, very simply and informally interact with business, and create a much stronger two-way communication, which then enhances mutual trust and strengthens brand image, and finally, after a large and long work can be seen increasing corporate visibility. In order to achieve this, business social networks have to be particularly active, as much as their users, or even more active.

Genslera, Völcknerb, Liu-Thompkins, Wiertz (2013) argue that the rise of social media and the associated possibilities of large-scale consumer-to-consumer interaction and easy user generation of content focus the spotlight on the importance of recognizing, and if possible managing, the multi-vocal nature of brand authorship advocated by the cultural branding view. Consumers in particular are more empowered by social media, as these technologies enable consumers to share their brand stories widely with peers.

Social networks are very popular. Several years ago only few people knew or used social networks (e.g., Facebook), nowadays almost everyone has and actively uses social networks.

Social networks are free. However this is not strictly true, however, visitors do not pay for their activities in social networks, and benefits can be much higher than from ads.

Social networks enhance two-way communication. Users much more conveniently and faster can communicate with companies via social networks, expressing their views and proposals.

Facebook, Twitter, Google+, Pinterest, and Linkedln are the most popular social networks. However, only few of them can be analyzed as the most popular social networks, because some of them have not gained great popularity in Lithuania. 
Social network Facebook in Lithuania is used by even $68 \%$ of the population, $46 \%$ of which use it on daily basis. Meanwhile, the second largest social network Google+ is used by almost $27 \%$ of the population, only $8 \%$ of them use it regularly. Professional social network Linkedln In Lithuania is used for almost $6 \%$ of the population. Other foreign popular social networks, such as: Twitter, Pinterest, or Tumblr are not popular in Lithuania.

Facebook. Facebook story began with a simple idea to create a single student's social network for high school students where they could easily communicate and share information. However, the situation has arisen that after the great success, Facebook has become accessible to everyone, no matter where they lived, worked, or studied. After several years it experienced great success, presumibly there were no persons who have not heard about this social network, although every fifth person in the world had a Facebook account.

It is important to provide information about your business when creating a Facebook account, in order the people visiting your account would immediately be aware of what you do, know the company's working hours, etc. However, the simplest, though the most important information should be mentioned: the level of prices and time, the information about the service, product's range and their groups, payment opportunity, phone number, and e-mail address.

Providing this information, it is important to arrange the following information about the company: it's short history, the services provided, its goals and values. It is advisable once in every three months to check whether the written information is correct and whether it is still relevant for that period.

It may happen that the company has moved, changed its working hours and contact information. It is important to provide this information in a somewhat looser style, but it should be interesting to read. It should not be written in a very formal and boring way, no one will read it and besides you might even lose potential customers.

For creating a good and attractive message, it is important to provide:

- photo and a brief description;

- few sentences about some recent events;

- good knowledge of your business or local community; 
INDEPENDENT JOURNAL OF MANAGEMENT \& PRODUCTION (IJM\&P)

http://www.ijmp.jor.br

v. 7, n. 2, April - June 2016

ISSN: 2236-269X

DOI: 10.14807/ijmp.v7i2.391

- $\quad$ special offers, discounts or promotions (briefly and clearly);

- information about the company's announcement in press.

Table 2: Facebook Statistics

\begin{tabular}{|c|c|}
\hline Facebook Statistics & Data \\
\hline Total number of monthly active Facebook users & $1,440,000,000$ \\
\hline Total number of mobile Facebook users & $874,000,000$ \\
\hline Increase of Facebook users from 2014 to 2015 & $12 \%$ \\
\hline Total number of minutes spent on Facebook each month & $640,000,000$ \\
\hline Percent of all Facebook users who log on in any given day & $48 \%$ \\
\hline Average time spent on Facebook per visit & 18 minutes \\
\hline Total number of Facebook pages & $74,200,000$ \\
\hline Facebook Demographics & Data \\
\hline Percent of 18-34 year people who check Facebook when they wake up & $48 \%$ \\
\hline $\begin{array}{l}\text { Percent of 18-34 year people who check Facebook before they get out of } \\
\text { bed }\end{array}$ & $28 \%$ \\
\hline Average number of friends per Facebook user & 130 \\
\hline Average number of pages, groups, and events a user is connected to & 80 \\
\hline Average number of photos uploaded per day & 205 \\
\hline Number of fake Facebook profiles & $81,000,000$ \\
\hline \multicolumn{2}{|l|}{ Global Facebook Reach Statistics } \\
\hline Number of languages available on the Facebook site & 70 \\
\hline Percent of Facebook users who are outside the United States & $75 \%$ \\
\hline Number of users who helped translate Facebook & 300,000 \\
\hline \multicolumn{2}{|l|}{ Facebook Platform Statistics } \\
\hline Average number of aps installed on Facebook each day & 20 million \\
\hline Total number of apps and websites integrated with Facebook & 7 million \\
\hline \multicolumn{2}{|l|}{ Every 20 Minutes on Facebook } \\
\hline Links shared & 1 million \\
\hline Friends requested & 2 million \\
\hline Messages sent & 3 million \\
\hline Facebook Company Statistics & Data \\
\hline
\end{tabular}


INDEPENDENT JOURNAL OF MANAGEMENT \& PRODUCTION (IJM\&P)

http://www.ijmp.jor.br

v. 7, n. 2, April - June 2016

ISSN: 2236-269X

DOI: 10.14807/ijmp.v7i2.391

\begin{tabular}{|l|r|}
\hline Highest Facebook stock price & $\$ 96.95$ \\
\hline Lowest Facebook stock price & $\$ 18.06$ \\
\hline Total number of Facebook employees & 4,619 \\
\hline Total Facebook revenue in 2014 & $\$ 12,466,000,000$ \\
\hline Total Facebook revenue in 2013 & $\$ 7,872,000,000$ \\
\hline Total Facebook revenue in 2012 & $\$ 5,090,000,000$ \\
\hline
\end{tabular}

Source: http://www.statisticbrain.com/facebook-statistics/

Google+. Google created and managed by the company Google. Google is a California-based, multinational internet company, providing digital products and services, such as: online search and advertising, cloud computing, and software. In May 2015, Google was ranked first amongst the most visited multi-platform web properties in the United States with 242 million U.S. unique visitors and a market share of 64.2 percent among the leading U.S search engine providers.

Google's market capitalization in February of 2015 was valued of 370.2 billion U.S. dollars. The same as Facebook and other social networks, Google+ allows you to create your intended personal or business accounts. People can share and look for the content as well as in all social networks. Google and creates your own miniversion of social network Facebook. Despite the existing similarities between these two social networks there are important further differences:

- Circles are considered as the most frequently mentioned and the largest Google+ advantages and differences, compared to Facebook. Just like in real life, people can create their desired groups (such as family, close friends, relatives, classmates, co-workers, etc.) in Google+ network. They can also add the desired parties to one or more circles. All this makes you to share information only with certain individuals.

"1+" - this is equivalent to Google+ Facebook "like" button. People, clicking on this button show that they like the content.

- Human mention. Writing a comment or message and pressing + sign and immediately without entering the person's or company name, they will be automatically informed about their commemoration. This makes very easy to share news or information to certain people, and companies can become much more active, more communicate with the public or customers. 
DOI: 10.14807/ijmp.v7i2.391

- "Hashtag". Makes it easier to find messages with a specific theme or content. Users create and use hashtags by placing the hash character (or number sign) pressing the \# in front or unspaced phrase, either in the main text of a message or at the end. Searching for that hashtag will present each message that has been tagged with it.

- Hangouts. Online chat with Google+ users, where at the same time can participate up to 10 people. This function does not require any additional software and at the end of the interview it is possible to place the call to the You Tube channel.

The search engine usage statistics for 2013:

- Google: $67.5 \%$

- Bing: $16.7 \%$

- Yahoo: $11.6 \%$

- Ask: $2.6 \%$

- AOL: $1.7 \%$

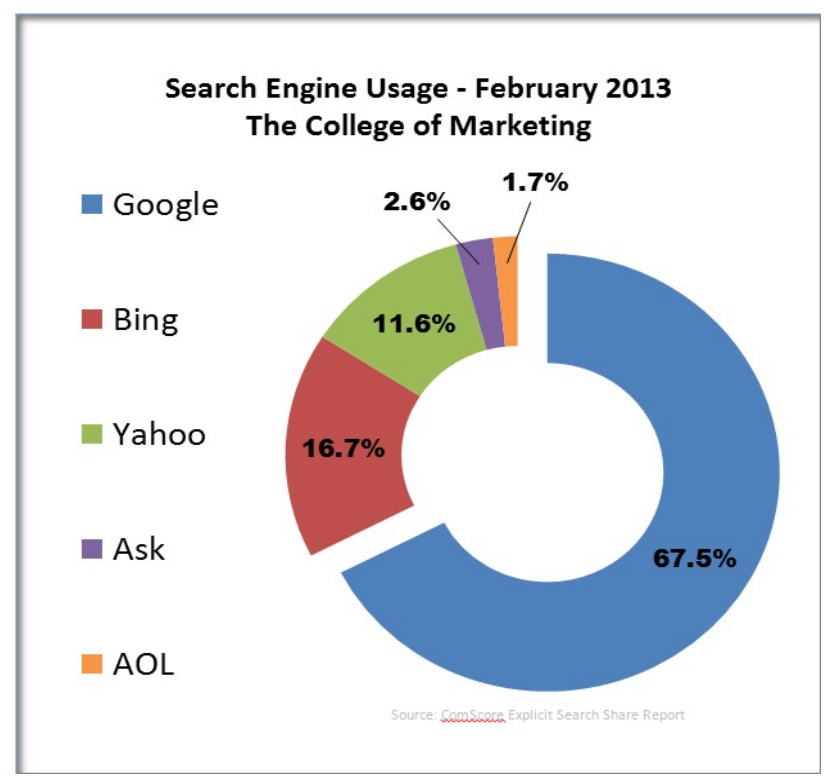

Figure 1: search engine usage statistics for 2013

Sources: http://www.collegeofmarketing.com/seo-guide/search-engine-usage/

It is advisable to post a new content at least once a day, however, it could be done several times a day. In addition, if your message mentions a person or 
DOI: 10.14807/ijmp.v7i2.391

company, that is worth to highlight, put its name with a + sign in order the people could be able to find it much easier.

\section{CONCLUSIONS}

Brands awareness could be raised through internet marketing tools, which notify, remind, and convince customers about their brands, products, or services. The client may encounter with the brand in various ways, for example, reviewing videos, playing games, spending time on the site or by communicating with other customers, watching advertisements.

In order to increase brand awareness it is necessary: to increase interaction with your brand, build positive brand associations, increase brand loyalty by linking it with the target audience, and motivate customers to get acquainted with your brand and associated products.

Publications in various media channels strengthen its positions in the consumer's mind, the brand becomes recognized. Brand awareness is created through advertising, promotion, selling, and public relations through internet. Internet marketing includes not only advertising on the websites, but also e-mails, and social networks.

Social media marketing involves the use of internet social media tools (Facebook, Twitter, and Linkedln) to reach consumers in innovative ways and to increase brand awareness. Social networking helps to promote the company and its brand awareness.

\section{REFERENCES}

AAKER, D. A. (1996). Measuring brand equity across products and markets.

California Management Review, v. 38, n. 3, p. 102 - 20.

ADJUGLER (2008). Powering digital profitability. Guide to online advertising. AdJuggler Inc.

ARORA, SH.; SHARMA, A. (2013). Social media: a successful tool of brand awareness. International Journal of Business and General Management (IJBGM), v. 2, n. 3, p. 1-14.

APERIA, T.; BACK, R. (2004). Brand Relations Management. Copenhagen Business School Press. p.25-46

CHAN,T. H.; LUENG, F. F.; PEKING, T.; DAVID K. (2015). Role of conventional ads in a digital age: effects of internet and conventional advertising and brand awareness 
and brand desire in China. International Journal fo Electronic Commerce Studies, v. 6, n. 1, p. 87-98. doi: 10.7903/ijecs.

LEYLAND, F. P.; PARENT, M.; BERTHON, P. R. (2011). Understanding Consumer Conversations around Ads in a Web 2.0 World. Journal of Advertising, p. 87-102.

CHI, HSU-HSIEN. (2011). Interactive Digital Advertising VS. Virtual Brand Community: Exploratory Study of User Motivation and Social Media Marketing Responses in Taiwan. Journal of Interactive Advertising, n. 12, p. 44-61.

CHI,K.H,YEH, H. R.; CHIEN, YANG, Y. T. (2009). The Impact of Brand Awareness on Consumer Purchase Intention: The Mediating Effect of Perceived Quality and Brand Loyalty. The Journal of International Management Studies, v. 4, n. 1, p. 135-144.

ČERNIKOVAITÉ, M. (2011). Brand value measurement models. Social Science Studies, v. 3, n. 3, p. 967-981. Retrieved from: https://www.mruni.eu/upload/iblock/6c2/11_Cernikovaite.pdf

DAVIDAVIČiENĖ, V.; GATAUTIS, R.; PALIULIS N.; PETRAUSKAS, R. (2009).

Electronic business. VGTU Technika: Vilnius. p.56-86

FACEBOOK STATISTICS (2015). Retrieved from

http://www.statisticbrain.com/facebook-statistics/

GENSLERA, S.; VÖLCKNERB, F.; LIU-THOMPKINS, Y.; WIERTZ, C. (2013). Managing Brands in the Social Media Environment. Journal of Interactive Marketing. n. 27, p. 242-256.

HASHMI, J. (2014). 6 benefits of internet marketing. Retrieved from:

http://clicktecs.com/6-benefits-of-internet-marketing.

HOEFFLER, S.; KELLER, K. L. (2003). The marketing advantages of strong brands. Journal of Brand Management, v. 10, n. 6, p. 421-45.

HOEFFLER, S.; KELLER, K. L. (2002). Building brand equity through corporate societal marketing. Journal of Public Policy \& Marketing, v. 21, n. 1, p. 78-89.

HOFFMAN, D. L.; FODOR, M. (2010). Can You Measure the ROI of Your Social Media Marketing? Mıtsloan management review, v. 52, n.1, p. 41-49.

HOMBURG, CH.; KLARMANN, M.; SCHMITT, J. (2010). Brand awareness in business markets: When is it related to firm performance? Internantional Journal of Research in Marketing, n. 27, p. 201-212. doi:10.1016/j.jiresmar.2010.03.004.

HONG-YOUL, H. (2004). Factors influencing consumer perceptions of brand trust online. Journal of Product \& Brand Management, v. 13 , p. 329-342.

HILL, D. (2011). Why website design is important. Retrieved from https://www.bopdesign.com/bop-blog/2011/09/why-website-design-is-important HSIAO, Y-H.; HSU, Y-H.; CHU, S-Y.; FANG, W. (2014). Is brand awareness a marketing placebo? Retrieved from:

http://www.knowledgetaiwan.org/ojs/index.php/ijbi/article/viewFile/468/125

GHODESWAR, B. M. (2008). Building brand identity in competitive markets:a conceptual model. Journal of Product \& Brand Management, v. 17, n. 1, p. 4-12, doi $10.1108 / 10610420810856468$. 
KARAM, A. A.; SAYDAM, S. (2015). An Analysis Study of Improving Brand Awareness and Its Impact on Consumer Behavior Via Media in North Cyprus (A Case Study of Fast Food Restaurants). International Journal of Business and Social Science, v. 6, n. 1, p. 66-80.

KELLER, K. L. (2009). Building strong brands in a modern marketing communications environment. Journal of Marketing Communications, v. $15, \mathrm{n}$. 2/3, p. 139-155. doi: 10.1080/13527260902757530.

KELLY, N. (2015). Measuring Social Media for Brand Awareness, n. 03.

KONIEWSKI, M. (2012). Brand awareness and customer loyalty. Retrieved from: http://www.research-pmr.com/userfiles/file/wp/Brand-Awareness-and-CustomerLoyalty.pdf

NETI, S. (2011). Social media and its role in marketıng. International Journal of Enterprise Compu International Journal of Enterprise Computing and Business Systems. v. 1 n. 2, p. 1-16.

PIKTURNIENĖ, I.; TREIGYTE், D. (2009). Brand awareness of the influence of leadership or tracking advantages. Young Scientists works. V. 23, n. 2, doi: 10.3846/1648-0627.2009.10.38-46.

PERCY, L.; ROSSITER, J. R. (1992). A model of brand awareness and brand attitude advertising strategies. Psychology \& Marketing, n. 9, p. 263-274.

ROESLER, P. (2015). Why and how you should use internet marketing to improve brand awareness. Retrieved from: http://mww.inc.com/peter-roesler/why-andhow-you-should-use-intemet-marketing-to-improve-brand-awareness.html

SARANGAN, B.; RAGEL, V. R. (2014). The impact of engagement with social media marketıng on brand awareness. Indian Journal of Research in Management, Business and Social Sciences. v. 2, n. 2, p. 129-136.

SEARCH ENGINE USAGE FACTS AND STATISTICS (2015). Retrieved from http://www.collegeofmarketing.com/seo-guide/search-engine-usage/

SOMAYEH, S.; AZMAN, A. B. (2013). An Evaluation of Factors Affecting Brand Awareness in the Context of Social Media in Malaysia. Asian Social Science; v. 9, n. 1.

SWEENEY, S.; MACLELLAN, A.; DOREY, E. (2006). 3g marketing on the internet : third generation internet marketing strategies for online success. Retrieved from http://web.b.ebscohost.com/ehost/ebookviewer/ebook/ztawmhh3d19fmjawodi2x19bt g2?sid=b9188cda-9114-4b48-b9fd-

c2da0c39b074@sessionmgr114\&vid=4\&hid=116\&format=eb

TRENGOVE, J. A.; MALCZYK, A.; BENEKE, J. (2011). Internet marketing. A highly practical guide to every aspect of internet marketing. Retrieved from

https://open.uct.ac.za/bitstream/item/3998/internet_marketing_textbook.pdf?sequenc $\mathrm{e}=1$

TSIMONIS, G.; DIMITRIADIS, S. (2014). Brand strategies in social media. Marketing Intelligence \& Planning, v. 32 n. 3, p. 329-344.

URBANSKIENE், R.; VAITKIENE், R. (2006). Brand management textbook. Kaunas: Technology. p. 32-42 
INDEPENDENT JOURNAL OF MANAGEMENT \& PRODUCTION (IJM\&P)

http://www.ijmp.jor.br

v. 7, n. 2, April - June 2016

ISSN: 2236-269X

DOI: 10.14807/ijmp.v7i2.391

VUKASOVIČ, T. (2013). Building successful brand by using social networking media. Journal of Media and Communication Studies. v. 5, n. 6, p. 56-63, doi:

10.5897/JMCS2013. 0352.

ZAILSKAITE-JAKSTE, L.; KUVYKAITE, R. (2013). Communıcatıon in socıal medıa for brand equity buıldıng. Economics and management, v. 18, n. 1, p. 142-153. 